\author{
ANNALS OF THE \\ UNIVERSITY OF CRAIOVA
}

Series: $\begin{aligned} & \checkmark \text { Biology } \\ & \checkmark \text { Horticulture } \\ & \checkmark \text { Food products processing } \\ & \text { technology } \\ & \checkmark \text { Environmental engineering }\end{aligned}$

Vol. XXVI (LXII) - 2021

\title{
RESEARCH ON THE ATTACK OF THE MONILINIA FRUCTIGENA PATHOGEN (ADERH. \& RUHL) HONEY ON THE APPLE, HARTIESTI LOCATION, ARGES COUNTY
}

\author{
Chiţulescu Lucian* \\ $1^{*}$ University of Agronomic Sciences and Veterinary Medicine from Bucharest, Bucharest \\ Doctoral School of Engineering and Management of Plant and Animal Resources \\ *Correspondence author. E-mail: lucian_chitulescu@yahoo.com
}

Keywords: pathogen, variety, apple, moniliosis

\begin{abstract}
The researches were carried out within the experiments regarding the attack of Monilinia fructigena on apple in the location of Hârtieşti, Argeş County, in the conditions of 2017. The biological material was represented by the varieties: Florina, Generos, Goldrush, Idared and Topaz. The observations were made in the untreated version and concerned the incidence of the attack on fruit and sprouts of the monitored varieties. The obtained results regarding the attack of the pathogen Monilinia fructigena in the conditions of 2017 show that the highest value of fruit attack incidence was found in the ldared variety where $F=35 \%$ followed by Topaz variety with a value of attack frequency of $29 \%$. Regarding the attack on sprouts, it was found that the same varieties had the highest values of incidence, $10 \%$ and $9 \%$, respectively. Among the analysed varieties, Florina variety registered the lowest values of the attack on both fruit and sprouts.
\end{abstract}

\section{INTRODUCTION}

Apple moniliosis caused by the pathogen Monilinia fructigena is manifested every year in apple orchards. The produced symptoms are visible in the attacked organelles, sprouts and fruit. The sprouts wither, turn brown and dry and the attack on fruit involves the appearance of brown rot, black rot and fruit mummification (Agrios, 2005; Gheorghies and Cristea, 2001; Chitulescu and Cristea, 2017). The pathogen responsible for the appearance of specific symptoms, makes the pathogen to cause significant fruit loss in both orchards and storage conditions (Van Leeuwen GCMet all., 2000; Berrie AM, 1989). Research has shown that abiotic (climatic conditions) and biotic (insects) play an important role in the spread of the pathogen and can ensure subsequent infections (Holb I., 2003; Holb and Scherm, 2008; Chitulescu and Cristea, 2019). The research area, Hartiesti location, Arges County, known for apple culture in Romania, is facing the attack of moniliosis (Chitulescu et Cristea, 2017). Knowledge of the biology and intervention to control the attack of moniliosis on apple has a particular importance for apple growers (Byrde et Willetts, 1977). The application of a treatment scheme that ensures an integrated control of diseases and pests specific to apple, that includes protection against the attack of moniliosis and that observes the recommendations for the products used ensures effectiveness in their control. The effectiveness of treatments in controlling diseases 
in continuous culture plants is a concern of agronomic research, in accordance with the new tested and approved molecules (Alexandru et all, 2019; Batra 1991).

\section{MATERIAL AND METHOD}

The experiments monitored the attack of Monilinia fructigena on the apple and the effectiveness of a treatment scheme in combating this pathogen. The researches took place in an apple orchard from Hartiesti location, Arges County, in the conditions of 2017. The biological material was represented by the apple varieties Florina, Generos, Idared, Goldrush, Topaz cultivated in the research area. The observations took into account the determination of the incidence of the attack on sprouts and fruit. The intensity of the attack was considered maximum, knowing that the attacked organelles are completely destroyed by the pathogen attack. The frequency of the attack was calculated according to the formula: $F(\%)=n \times 100 / N$, where $F=$ frequency of the attack, $n=$ percentage of organs with specific attack, $N$ $=$ total number of analysed organs. The intensity of the attack is considered to be $100 \%$ due to the degree of the attack equivalent to its frequency. The efficacy of the treatment is calculated according to the formula $E(\%)=(F m-F v) / F m$, where: $E=$ efficacy $(\%), \mathrm{Fm}=$ attack frequency for the untreated variant (\%), $\mathrm{Fv}=$ attack frequency for the treated variant (\%). The data regarding the climatic conditions of the year were taken from the Meteorological Station - from the Institute for Fruit Growing in Pitesti - Mărăcineni. Statistical analysis of experimental data was performed with the ANOVA program.

\section{RESULTS AND DISCUSSIONS}

1. Meteorological data

In 2017, the average annual air temperature registered a high value of $11.0^{\circ} \mathrm{C}$, exceeding the multiannual values by $1.1^{\circ} \mathrm{C}$. The amount of precipitation (632.3 $\mathrm{mm}$ ) decreased by $45 \mathrm{~mm}$ compared to the multiannual average $(677.3 \mathrm{~mm})$ (Figure 1).

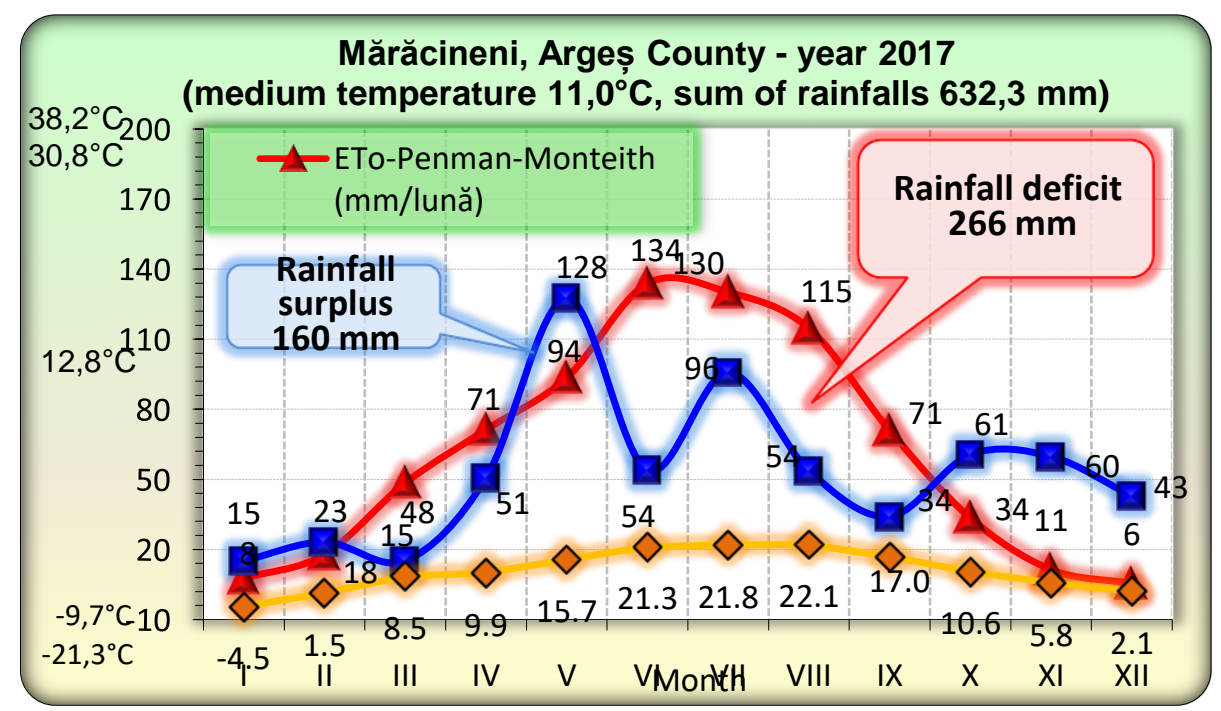

Figure 1.Climatic conditions of 2017 in Mărăcineni, Argeș County 
Comparing the water regime of 2017 with the multiannual values, we find that there were deviations, both in terms of surplus and, especially, rainfall deficit.

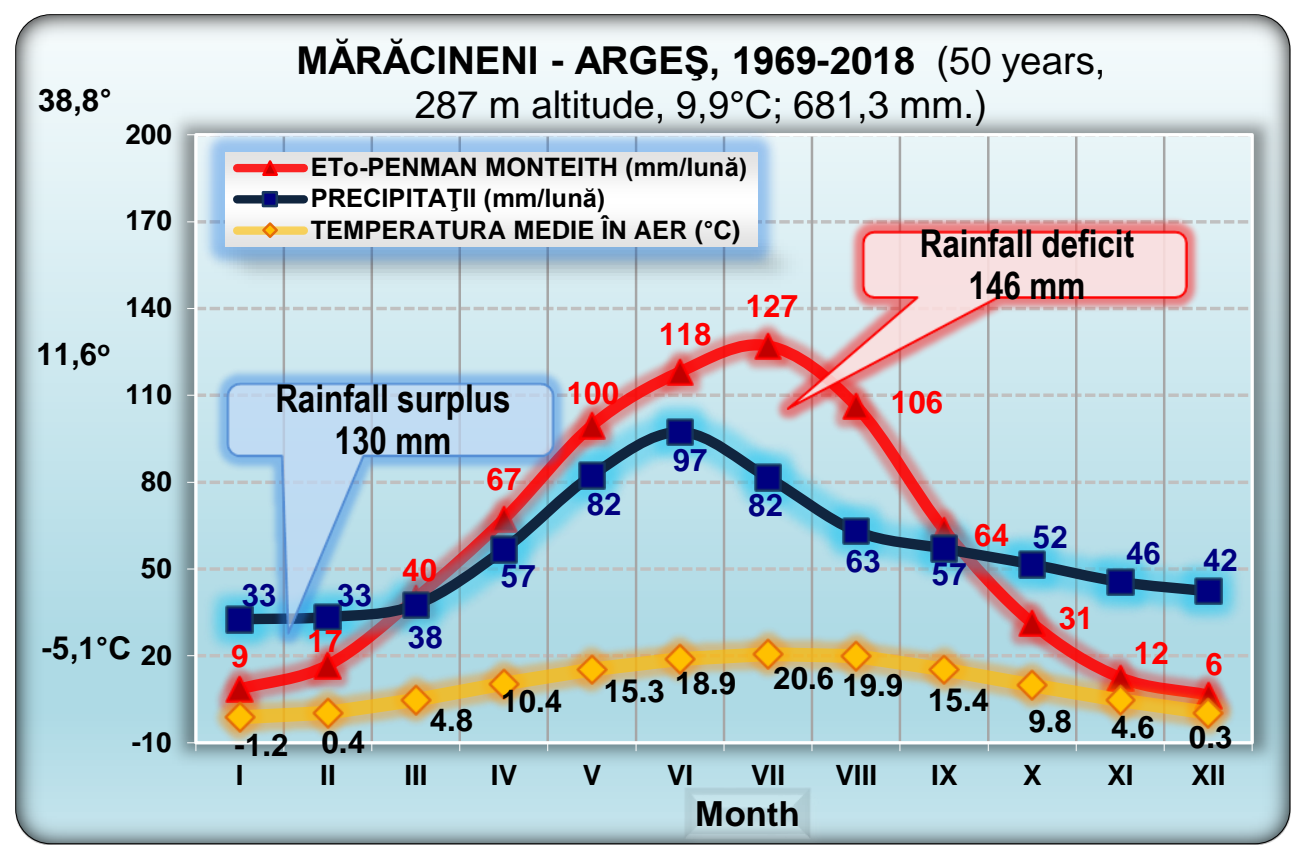

Figure 2. Multiannual meteogram in Mărăcineni, Argeș County

Thus, the large rainfall surplus of $160 \mathrm{~mm}$ exceeded by $40 \mathrm{~mm}$ the multiannual value, especially in May, and the deficit of $266 \mathrm{~mm}$ exceeded by 116 $\mathrm{mm}$ the normal value, being recorded in July and August (Figure 2 ).

2. Results of Monilinia fructigena attack on fruit

The data regarding the attack of the pathogen Monilinia fructigena on the fruit in 2017 are presented in Table 1. Under the conditions of 2017, for the control variety, Idared, the value of the frequency of the fruit attack was $35 \%$. For the Topaz variety, the value of the fruit attack frequency was $29 \%$ and for the Generos variety, $\mathrm{F}=24 \%$. For the Goldrush variety, the attack frequency values of $28 \%$ were calculated. Regarding Florina, in 2017 it was found that the value of the attack frequency on fruit was $20 \%$, the lowest value in the conditions of this year, compared to the studied varieties.

Table 1.

Frequency of the attack of the Monilinia fructigena pathogen on fruits, year 2017, Hârtieşti location, Argeş County

\begin{tabular}{|l|l|l|l|}
\hline \multirow{2}{*}{ Variety } & \multicolumn{1}{|c|}{2017} & \multicolumn{1}{c|}{ Difference } & \multicolumn{1}{c|}{ Significance } \\
\cline { 2 - 4 } & $\mathrm{F}(\%)$ & 2017 & 2017 \\
\hline Generos & 24 & -11 & 000 \\
\hline Topaz & 29 & -6 & 000 \\
\hline
\end{tabular}




\begin{tabular}{|l|l|l|l|}
\hline Goldrush & 28 & -7 & 000 \\
\hline Florina & 20 & -15 & 000 \\
\hline Idared (control) & 35 & 0 & - \\
\hline \multirow{3}{*}{$\mathrm{DL}$} & $5 \%$ & 1,885 & \\
\cline { 2 - 4 } & $1 \%$ & 2,680 & \\
\cline { 2 - 4 } & $0,1 \%$ & 3,880 & \\
\hline
\end{tabular}

The analysis of the results in Table 1 showed that the differences in the researched varieties were statistically assured, being interpreted very significantly in a negative way. This confirms that the values of the attack frequency on the fruit were lower than those of the Idared variety, the behaviour of the varieties at the micromycete attack being superior to the control.

\section{Results of the Monilinia fructigena attack on sprouts}

The results of the observations regarding the attack of the pathogen Monilinia fructigena were presented in Table 2. Regarding the frequency of the attack on sprouts, it was found that in the varieties Generos, $F=5 \%$, Topaz with $F=9 \%$ and Goldrush with $\mathrm{F}=8 \%$. For Florina variety, the value of the moniliosis attack frequency on sprouts in 2017 was $4 \%$ and for the Idared variety, the value was $F=10 \%$.

Table 2.

Frequency of Monilinia fructigena fungus attack on shoots, year 2017, Hârtieşti location, Argeş County

\begin{tabular}{|l|l|l|l|}
\hline \multirow{2}{*}{ Variety } & 2017 & Difference & Significance \\
\cline { 2 - 4 } & $\mathrm{F}(\%)$ & 2017 & 2017 \\
\hline Generos & 5 & -5 & 000 \\
\hline Topaz & 9 & -1 & $\mathrm{~ns}$ \\
\hline Goldrush & 8 & -2 & 0 \\
\hline Florina & 4 & -6 & 000 \\
\hline Idared (control) & 10 & 0 & - \\
\hline \multirow{3}{*}{ DL } & $5 \%$ & 1,227 & \\
\cline { 2 - 4 } & $1 \%$ & 1,744 & \\
\cline { 2 - 4 } & $0,1 \%$ & 2,525 & \\
\end{tabular}

Statistical analysis of the data shows that compared to the control variety, the differences were interpreted very negatively for Generos and Florina varieties and significantly negative for the Goldrush variety. As a result, there was a reduction in the attack on the sprouts compared to the control. In the case of the Topaz variety, the differences were insignificant, the value of the incidence of moniliosis attack on sprouts being close to that of the Idared variety (Table 2). 


\section{CONCLUSIONS}

The results obtained regarding the attack of Monilinia fructigena pathogen in the conditions of 2017 show that the highest value of the incidence of fruit attack was found in Idared variety $(F=35 \%)$ in the untreated variant followed by Topaz variety with an attack frequency value of $29 \%$. Regarding the attack on sprouts, in the conditions of the experimental year 2017, it was found that the same varieties presented the highest values of incidence.

\section{BIBLIOGRAPHY}

Agrios G., 2005. Plant pathology. Fiftth edition. Department of Plant pathology, University of Florida. Elsevier Academic Press.

Alexandru I., Cristea S., hoza D., 2019. Effectivenes of treatments on the attack of Polystigma rubrum and Stigmina carpóphila on plum in Soimari location, Prahova County. Scientific Papers Series B-Horticulture, volume 63, Issue 2,pages 79-82.

Batra I. R. 1991. World species of Monilinia (Fungi): Their ecology, biosystematics and control. J.Cramer (Gebruder Borntraeger), Berlin-Stuttgard. 246 pp.

Berrie A.M., 1989. Storage rots of apple and pear in South East England 198088: incidence and fungicide resistance. In: Gessler, B. K.Ed IOBC Bulltin, vol. II. Integreted control of pome fruit diseases, Locarno, Switzerland,IOBC: 229-239.

Byrde R.J.W \& Willetts H. J., 1977. The Brown Rot fungi of Fruits: Their Biology and Control. Oxford: Pergamon Press.

Chitulescu L., Cristea S., 2017. Researches on the reaction of apple varieties to Monilinia fructigena fungus attack. Journalof Biotechnology 256 S(2017) S44S116,S100. http://dx.doi.org/10.106/ j.jbiotec.2017.06.1142

Chitulescu L., Cristea S., 2017. Efficacy of some treatments on Monilinia fructigena (Aderh. \& Ruhl.) honey fungus attack on apple. Analele Universităţii din Craiova, seria Agricultură - Montanologie - Cadastru (Annals of the University of Craiova - Agriculture, Montanology, Cadastre Series) Vol. XLVII.

Chitulescu L., Manole M.S., Delian E., Cristea S. 2019. The effect of abiotic factors on the in vitro developmentof Monilinia fructigena fungus (Aderh. \& Ruhl.) honey, isolated from the apple. Scientific Papers. Series B, Horticulture. Vol. LXIII, No. 2, 2019 Print ISSN 2285-5653, CD-ROM ISSN 2285-5661, Online ISSN 22861580, ISSN-L 2285-5653.

Chitulescu L., Cristea S. 2017. Researches regarding the attack of the Monilinia fructigena fungus (Aderh. \& Ruhl.) honey on some varieties of apple, Hartiesti location, Arges county.

Gheorghieş C., Cristea S. 2001. Fitopatologie Vol 1, Edit. Ceres, Bucuresti.

Holb I., 2003 - Analyses of temporal dynamics of brown rot development on fruit in organic apple production. Int. J. Hortic. Sci. : 97- 100.

Holb I., Scherm H. 2008. Quantitative relationships between different injuri factors and development of brown rot caused by Monilinia fructigena in integrated and organic apple orchards, Phytopathology 98: 79-86.

Van Leewen G. C.M., Stein A., Holb I., Jerger M.J., 2000. Yield loss caused by Monilinia fructigena in Dutch orchands. European Journal of Plant Pathology 75: 534-432. 